Gulyás, László Szabolcs. "Slíz, Mariann. 2017. Personal Names in Medieval Hungary. Hamburg: Baar Verlag. 215 pp." Hungarian Cultural Studies. e-Journal of the American Hungarian Educators Association, Volume 12 (2019) DOI: $10.5195 /$ ahea.2019.369

\title{
Slíz, Mariann. 2017. Personal Names in Medieval Hungary. Hamburg: Baar Verlag. 215 pp.
}

\author{
Reviewed by László Szabolcs Gulyás ${ }^{1}$
}

Onomastic studies have a long tradition in Hungarian linguistics. In the last century scholars of this field have mainly focused on two great topics: place names and personal names. Place-name studies, however, took the lead and proved to be more popular among researchers than personal names. This is regrettable, since personal names are an important source of the medieval period, useful not only for linguists but also for historians. When carefully studied, personal names can tell us much about the name bearers themselves, including an individual's social status, their possible ethnic affiliations, internal and external attributes and family relations. Therefore, the recently published English-language monograph by Mariann Slíz (of the Eötvös Loránd University in Budapest), a well-known expert on this topic in Hungary, is a welldeserved achievement. The book's publisher is the German Baar Verlag, which is famous for its frequent publication of linguistics works. In her book, Slíz analyses medieval Hungarian personal names and the method of name-giving in that period from several aspects.

Once we start reading the book, though, we face a minor contradiction between its title and actual content, because while the former promises to cover Hungarian name-giving practices throughout the entire Middle Ages (which in Hungarian standards lasted from 1000 to 1526), the analysis relates mostly only to the thirteenth and fourteenth centuries. This focus probably derives from Slíz's specific period of expertise, as she wrote her Ph.D. thesis (2010) on personal names in the first half of the Hungarian Angevin Era (1301-1382), and the present work is based on her thesis. Although the important transformation of the Hungarian name structures, namely the spread of family names, became widespread only in the fifteenth century, which is an especially exciting phase in the history of Hungarian language, the author fortunately regularly looks forward in her book to the naming practices of later times as well.

Following the Introduction, Slíz divides her book into six major chapters, each of which includes many subchapters. As the author explains in the Introduction, earlier studies similar to hers (for instance those by Jolán Berrár and Katalin Fehértói) surveyed the topic of personalname giving until the end of the thirteenth century. Yet, the number of available written sources containing a large number of personal names increases explosively from the beginning of the fourteenth century, and that would call for further minute examination of this practice, which is just what Slíz does in her novel work.

The book's relatively short second chapter ("The History of the Hungarian Research of Historical Personal Names") offers a brief summary of previous research on Hungarian personal

${ }^{1}$ gulyaslsz@freemail.hu

$($ (c) $)$ EY

ULIS D-Sorke
New articles in this journal are licensed under a Creative Commons Attribution 4.0 International License.

This journal is published by the University Library System of the University of Pittsburgh as part of its D-Scribe Digital Publishing Program and is cosponsored by the University of Pittsburgh Press 
Gulyás, László Szabolcs. “Slíz, Mariann. 2017. Personal Names in Medieval Hungary. Hamburg: Baar Verlag. 215 pp." Hungarian Cultural Studies. e-Journal of the American Hungarian Educators Association, Volume 12 (2019) DOI: 10.5195/ahea.2019.369

names. This research started back in the eighteenth century and increased in the nineteenth; interestingly however, it was first initiated not by linguists but rather by historians, who utilized medieval personal names for genealogical research. The first important scholars to investigate these names through the prism of linguistics were Péter Cséplö and Frigyes Pesty, both active in the last quarter of the nineteenth century. In the mid twentieth-century, starting with the work of Loránd Benkő, the leading linguist of Hungarian research of the time, it became evident that without collecting a large number of personal names and creating a database of names, it would not be possible to investigate the corpus of such names. Katalin Fehértói was the first researcher to undertake this task, which she did by investigating a collection of 26,000 personal names from the Árpád Age (1000-1301). Fehértói was followed by several linguists, most notably János N. Fodor and Slíz, the author of the present book, who worked with fourteenth- and fifteenthcenturies charters. By now it has become fundamental that names are to be examined within the context of these charters and also that it is essential to establish the social background of the name bearers.

The third chapter ("Sources and Possibilities of the Study of Medieval Hungarian Personal Names") and the following fourth chapter in the book ("Methodological Questions of Data Processing") together constitute the most important part of Slíz' s work. In these chapters, the author presents an ambitious summary on the methodology of investigating medieval personal names as well as specifies the research possibilities of using name data for historical investigations. She introduces the languages of the available sources (Latin, Czech, German and Croatian), the kinds of written documents that support her study (tithe registers, charters, narrative sources), and she draws our attention to the fact that the data obtained in this way is disproportionate. This is so because the collected names do not show us the real proportion of male and female names within the Hungarian society, or the real proportion of social classes, and they are also very unequal in terms of geography because they were collected from different parts of the country but not from the entire territory of the Kingdom.

The author presents her corpus of about 14,000 personal names of the period between 1301 and 1342. The imbalance of this data is visible: among the secular (or first or given) names only 270 are female while 7863 are male names. The distribution of social status is similarly unequal with 6743 landholders, 277 serfs, 246 citizens, 157 market-town inhabitants, and 440 unclassified names. The situation is similar regarding ecclesiastical name-bearers with 1095 names coming from the ecclesiastical middle class and 4085 connected to lower-class priests. The crucial problem during data collection is the identification of individuals bearing these names by their social situation, place of residence and also the clarification of chronological issues regarding their lives. In ascertaining one's social status, the status markers appearing before the name (e.g., nobilis, civis, iobagio meaning serf, servus, magnificus, magister etc.) play a major role. Another important issue is the person's ethnic affiliation, because the medieval Hungarian Kingdom was a multicultural state including not only Hungarian but also Slavic, Germanic, Walloon, Romanian, and Turkic (also called Pechenegs or Cumans) populations. This multilingualism was not unique in the area and had a serious impact on the customs of namegiving.

Because the spelling of some names may vary in some diplomas (e.g., Mathias instead of Matheus, Georgius instead of Gregorius etc.), and because at that time names could have several variations (for example, Benedictus could also appear as Bene, Bende, Benke etc.), researchers must be careful in their investigation. The last important question in these two pivotal chapters is 
Gulyás, László Szabolcs. "Slíz, Mariann. 2017. Personal Names in Medieval Hungary. Hamburg: Baar Verlag. 215 pp." Hungarian Cultural Studies. e-Journal of the American Hungarian Educators Association, Volume 12 (2019) DOI: 10.5195/ahea.2019.369

the origin of a name. As previous research has demonstrated, before the founding of the Christian State, Hungarian personal names were mainly of secular and Hungarian origin, but by the end of the Árpád era, more than half of the known personal names were of foreign origin, and a large part of those were of ecclesiastical origin. The foreign Christian names were mainly of Greek and Latin origin, and there were also Turkic, Slavic, Germanic, and French loan names.

The next and longest chapter ("Given Names in Medieval Hungary"), the fifth in the book, deals with medieval Hungarian given names. As Slíz illustrates, from the beginning of the Árpád Era, names of Hungarian origin containing a single element were widely used in the country, and generally these names referred directly to some of the attributes of the name bearer. Later, however, these names were gradually replaced by biblical names that no longer referred to any attributes of the person carrying them. In this chapter, the author describes observable changes in the use of names with the help of more than fifty carefully-edited tables that cover all the important components of name-giving. Regarding male names, there are no great differences in the spread of first names in relation to specific social groupings. The most common names (irrespective of social standings) are János (John), Miklós (Michael), Péter (Peter), Pál (Paul) and István (Stephen). Similarly, no significant regional differences can be observed in this category. Yet, for instance, male names deriving from German were more common in cities than in smaller places. This is not a surprise, as a considerable part of the population in Hungarian cities had at that time been formed by Germans. Another important finding of Slíz's investigation is that the proportion of names of Hungarian origin decreased by some three percents by the middle of the fourteenth century. As far as women's names are concerned, we have much less data. Among citizens and nobles, the most frequent female names were Erzsébet (Elizabeth), Margit (Margaret) and Katalin (Katherine); and among peasants, the popularity of Ilona (Helen) is to be highlighted. Otherwise, the origin of female names did not display any difference in comparison with that of the male names.

Having carefully analyzed the issue of name variants in a separate subchapter of the fifth chapter, the author goes on to name-giving motivations and she is indeed able to discover several special types of these. In the case of descriptive names, the name distinguishes the bearer by his or her special characteristics (like, for instance, Seuchee meaning Blond). Names that testify to magical thinking are a unique category. These were frequent before the conversion to Christianity but they are discernible in the material even as late as in the Árpád Age. With these names parents wanted to influence the life of the child (for example by naming them Genuruh meaning Beautiful), or they wished to protect a child from malicious ghosts (as happens with a name like Numel, meaning Not Alive).

As the author argues, the local cults of saints also played an important role in the naming practice. It can be observed that the names of regional and especially Hungarian saints were fashionable in the Hungarian Kingdom (e.g., István and László). At the same time, it is striking that the name of Virgin Mary (Mária), the protector saint of Hungary since the time of St. Stephen, had little influence on naming practices. It is also an interesting phenomenon that no clear geographical correlation can be evinced between the spread of patron-saint churches and the appearance of corresponding names within the same localities. The last important part of this examination is addressed to literary name-giving. As Slíz states on the basis of her data and previous research, these given names appeared mainly among the nobles and originated from Breton and Classical mythology, and they were transmitted through chivalric culture (examples 
Gulyás, László Szabolcs. "Slíz, Mariann. 2017. Personal Names in Medieval Hungary. Hamburg: Baar Verlag. 215 pp." Hungarian Cultural Studies. e-Journal of the American Hungarian Educators Association, Volume 12 (2019) DOI: 10.5195/ahea.2019.369

of such names are: Artheus - Arthur, Izola - Isolde, Achilles, Paris, Hector and so on); yet such names became rare by the second half of the fourteenth century.

The next great chapter ("Bynames and Family Names"), the sixth in the book, discusses the problem of bynames and family names. Although multi-element name-systems had already appeared in Hungary by the fourteenth century, the chronological development of this phenomenon is contested. As we can read, there is no real consensus in Hungarian research on the formation of family names, as Hungarian linguists date the origin of this practice between the thirteenth and seventeenth centuries. Likewise, there is no consensus on the very cause of the appearance of family names in the country. In Hungarian historical research, two distinct types of surnames seem to be very important: names referring to professions and names deriving from place names. The author discusses this issue in detail, presenting the most important types of bynames and family names, and tying her discussion to the structure and motivations behind these developments. She also pays special attention to the most important components of contemporary name structures (namely, dictus, de preposition, and filius-word). As Slíz sees, in the development of bynames and family names, Latin literacy, social situation, property-law, and sometimes snobbery could all play a role. In the closing seventh chapter of the book ("From the Middle Ages to Present Day") the author summarizes the development of Hungarian personal names from the end of the Middle Ages to the Modern Age. The most important change in this era was the consolidation of the multi-element name system and, from 1895 and on, the legal regulation of naming.

Mariann Slíz's Personal Names in Medieval Hungary is an innovative and important presentation of both the findings of her research and the past achievements of Hungarian onomastics, all of which are now made accessible in English to a wide range of international readership. Due to its prompt presentation of medieval Hungarian personal names, name-giving and name-using practices, as well as for its solidly grounded methodology and handling of sources, this book will be of interest not only to scholars working in the field of name research but also to medievalists working on medieval social history. 